\title{
Herbicide Resistance of Centaurea cyanus L. in Poland in the Context of Its Management
}

\author{
Marta Stankiewicz-Kosyl ${ }^{1, * \mathbb{D}}$, Małgorzata Haliniarz ${ }^{2, *} \mathbb{D}$, Mariola Wrochna ${ }^{1}$, Agnieszka Synowiec ${ }^{3}$ (D), \\ Anna Wenda-Piesik ${ }^{4}$ (D), Ewa Tendziagolska ${ }^{5}$, Magdalena Sobolewska ${ }^{6}$, Krzysztof Domaradzki ${ }^{7}$, \\ Grzegorz Skrzypczak ${ }^{8}$, Witold Lykowski ${ }^{9}$, Michał Krysiak ${ }^{10}$, Marcin Bednarczyk ${ }^{11}$ \\ and Katarzyna Marcinkowska ${ }^{12}$ (D)
}

Citation: Stankiewicz-Kosyl, M.; Haliniarz, M.; Wrochna, M.; Synowiec, A.; Wenda-Piesik, A.; Tendziagolska, E.; Sobolewska, M.; Domaradzki, K.; Skrzypczak, G.; Łykowski, W.; et al. Herbicide Resistance of Centaurea cyanus L. in Poland in the Context of Its Management. Agronomy 2021, 11, 1954. https://doi.org/10.3390/ agronomy11101954

Academic Editor: Judith Wirth

Received: 10 June 2021

Accepted: 23 September 2021

Published: 28 September 2021

Publisher's Note: MDPI stays neutral with regard to jurisdictional claims in published maps and institutional affiliations.

Copyright: (c) 2021 by the authors. Licensee MDPI, Basel, Switzerland. This article is an open access article distributed under the terms and conditions of the Creative Commons Attribution (CC BY) license (https:/ / creativecommons.org/licenses/by/ $4.0 /)$.
1 Department of Plant Protection, Institute of Horticultural Sciences, Warsaw University of Life Sciences-SGGW, Nowoursynowska 166, 02-787 Warsaw, Poland; mariola_wrochna@sggw.edu.pl

2 Department of Herbology and Plant Cultivation Techniques, University of Life Sciences in Lublin, Akademicka 13, 20-950 Lublin, Poland

3 Department of Agroecology and Crop Production, Faculty of Agriculture and Economics, University of Agriculture in Krakow, Al. Mickiewicza 21, 31-120 Krakow, Poland; a.synowiec@urk.edu.pl

4 Department of Agronomics, Faculty of Agriculture and Biotechnology, UTP University of Science and Technology, Al. Kaliskiego 7, 85-796 Bydgoszcz, Poland; apiesik@utp.edu.pl

5 Institute of Agroecology and Plant Production, Wrocław University of Environmental and Life Sciences, pl. Grunwaldzki 24a, 50-363 Wrocław, Poland; ewa.tendziagolska@upwr.edu.pl

6 Department of Agroengineering, The West Pomeranian University of Technology in Szczecin, Ul. Papieża Pawła VI 3, 71-459 Szczecin, Poland; magdalena.sobolewska@zut.edu.pl

7 Department of Weed Science and Soil Tillage Systems, Institute of Soil Sciences and Plant Cultivation-State Research Institute, Orzechowa 61, 50540 Wrocław, Poland; k.domaradzki@iung.wroclaw.pl

8 Agronomy Department, Faculty of Agronomy and Bioengineering, Poznań University of Life Sciences, 60-632 Poznan, Poland; gsweed@up.poznan.pl

9 BASF Polska Sp. z o.o., Al. Jerozolimskie 142B, 02-305 Warsaw, Poland; witold.lykowski@basf.com

10 Bayer Sp. z o.o., Crop Science, Al. Jerozolimskie 158, 02-326 Warsaw, Poland; michal.krysiak@bayer.com

11 Syngenta Polska Sp. z o.o., ul. Szamocka 8, 01-748 Warsaw, Poland; marcin.bednarczyk@syngenta.com

12 Institute of Plant Protection-National Research Institute, ul. Władysława Wegorka 20, 60-318 Poznań, Poland; k.marcinkowska@iorpib.poznan.pl

* Correspondence: marta_stankiewicz_kosyl@sggw.edu.pl (M.S.-K.); malgorzata.haliniarz@up.lublin.pl (M.H.)

\begin{abstract}
Cornflower (Centaurea cyanus L.), one of the main weeds found among winter crops in Poland, has developed herbicide resistance (HR) to acetolactate synthase (ALS) herbicides, a finding first reported in 2006, and in recent years, farmers have been complaining about inadequate chemical control of this weed. This study aimed to characterise the current state of cornflower HR to ALS inhibitors and synthetic auxins in Poland and the agricultural practices in fields with herbicide-resistant populations. From 2017 to 2020, 159 seed samples together with the field history were collected across the country and biological tests performed in glasshouses. This revealed that 47 populations of $C$. cyanus were cross-resistant to both tribenuron and florasulam, 28 and 8 populations were single resistant to tribenuron and florasulam, respectively, and 3 populations had developed multiple resistance to both ALS inhibitors and synthetic auxins, i.e., 2,4-D and dicamba. Resistant populations were found mostly frequent in northern Poland, but also in the eastern and western parts of the country. Based on a survey of farmers, the resistant populations were found in winter crops regardless of the tillage system $(77 \%$ of fields with HR cornflower were mouldboard ploughed). Based on the proposed population treatment (PT) index showing the frequency of herbicide use during three consecutive seasons on farms with HR cornflower, the average PT for all the surveyed farms was 5.4. The highest PT of 7.4 was found in the province of Warmia-Masuria in northern Poland.
\end{abstract}

Keywords: cornflower; tribenuron-methyl; florasulam; 2,4-D; dicamba; population treatment; survey method; biological test 


\section{Introduction}

In modern agriculture, the phenomenon of herbicide-resistant weeds represents a serious threat to both crop yield [1,2] and agricultural biodiversity [3]. Worldwide herbicide resistance concerns 1094 unique cases (weed species $\times$ site of action) [4], with the most troublesome being grass weeds $[4,5]$. In Europe, the main herbicide-resistant weeds also include monocotyledonous species, i.e., Alopecurus myosuroides in north-western Europe and Apera spica-venti in central and eastern European countries [5], but also a dicotyledonous Papaver rhoeas in the Mediterranean basin [6,7]. In Poland, the situation is different since, according to Heap's list, the majority of herbicide-resistant cases concern dicotyledonous weeds (12 different species) and only four monocotyledonous species, which together constitute 25 cases of herbicide resistance in the country [4]. The first cases of herbicide resistance were identified in Poland in the early 1980s and concerned weeds that were resistant to photosystem II inhibitors, e.g., Conyza canadensis and Capsella bursa-pastoris, followed by Amaranthus retroflexus and Chenopodium album $[8,9]$. These are common dicotyledonous species in the country and are found among a variety of crops and also in orchards. Interestingly, Heap's list for Poland also features rarer weed species that have evolved herbicide resistance, such as Epilobium ciliatum, which is resistant to photosystem II inhibitors in orchards [10], and cornflower (Centaurea cyanus L.), which is resistant to acetolactate synthase (ALS) inhibitors (Herbicide Resistance Action Committee (HRAC) group 2) as well as dicamba (HRAC 4).

Cornflower is an annual dicotyledonous weed from the Asteraceae family that emerges mostly in autumn and overwinters in winter cereals and winter oilseed rape [7,11,12]. Nowadays, its status depends on the region, with it being found more rarely in western Europe [12-14] and more frequently in central Europe [11,15-18]. It is believed that agricultural intensification and a decrease in insect pollinators could be behind the decline of cornflower in Europe [7]. However, cornflower is spreading throughout the USA as an invasive species in native grasslands and prairies, especially in the northwest of the country [19].

A recent review of $C$. cyanus herbicide resistance in Poland lists five confirmed populations that are resistant to different ALS inhibitors [7]. The first case of herbicide-resistant cornflower in Poland was identified in 2006 by Marczewska and Rola [20]. The population was resistant to chlorsulfuron (HRAC 2) and originated from southwest Poland. The second report of $C$. cyanus resistance to ALS inhibitors was provided by Adamczewski and Kierzek [21]. The population was located in north-east Poland, and its resistance to ALS inhibitors, i.e., tribenuron methyl and chlorsulfuron, was confirmed by a set of greenhouse biotests. In Poland, herbicides from the group of ALS inhibitors currently play a crucial role in the chemical control of cornflower in winter cereals and oilseed rape [7]. Thus, weed resistance to these herbicides is one of the main problems in Poland but also more widely in Europe [5]. A single C. cyanus population resistant to dicamba was noted in 2010-2012 in north-east Poland (communicated by Prof. K. Adamczewski) [4]. Resistance to synthetic auxins has been reported in 41 weed species worldwide, most of which are also resistant to multiple synthetic auxin chemical families [4]. Two Centaurea species have been reported as being resistant to synthetic auxins. Centaurea solstitialis in Washington State in the US was selected for resistance to picloram along roadsides and was later classified as being cross-resistant to clopyralid, triclopyr, dicamba and 2,4-D [22,23]. Centaurea stoebe in Canada was observed to be resistant to clopyralid and picloram in extensively managed rangeland [24].

The issue of herbicide resistance has been increasing in Poland in recent years [25]. This may be due to the intensification of agricultural production in the country, correlated with intensified use of agrochemicals and the simplification of crop rotations. In the last few decades in Poland, there has been a significant increase in the production of winter crops, especially winter wheat and winter oilseed rape $[26,27]$, and thus overwintering weeds such as cornflower pose a greater and more visible threat to crop yields. This research was initiated by farmers highlighting the ineffectiveness of chemical control of $C$. cyanus. 
The objectives of this study were to: (1) characterise agricultural practices in fields with herbicide-resistant cornflower and (2) present the up-to-date status of herbicide resistance in cornflower to selected herbicides from the group of ALS inhibitors and synthetic auxins in Poland.

\section{Materials and Methods}

\subsection{Collection of Surveys and C. cyanus Seeds}

Surveys were undertaken and potentially herbicide-resistant seeds of C. cyanus were collected between 2017 and 2020 on 159 farms across Poland. Seeds were collected on farms where farmers reported cornflower control difficulties. The study was a part of the 3-year national project entitled "Anti-resistance strategy in weed management as an important factor in the sustainable development of agroecosystems" concerning herbicide resistance in 4 important agricultural weeds in Poland: C. cyanus, P. rhoeas, A. myosuroides and $A$. spica-venti.

The survey covered farming methods implemented in the last 3 years on fields in which potentially resistant $C$. cyanus was growing (in the year of seed sampling, as well as 1 year and 2 years before). More specifically, the survey included questions about crop sequence, soil tillage methods, and details of herbicide control of C. cyanus and other dicotyledonous weeds in those fields.

The results of the surveys were compiled and the frequency of use of different HRAC groups and active substances of herbicides applied by farmers to control C. cyanus was analysed. Moreover, to calculate the frequency of application of each active substance in the herbicide used by farmers per resistant and susceptible population in the last 2 or 3 years, the population treatment (PT) indicator was proposed:

$$
\mathrm{PT}=\frac{\text { total number of active ingredient applications in two or three successive growing seasons }}{\text { number of populations resistant to an active ingredient or susceptible } *}
$$

* number of populations resistant to tribenuron-methyl and florasulam, or to tribenuronmethyl only, or to florasulam only, or resistant to synthetic auxins, or susceptible to all active ingredients tested.

The calculation of the population treatment (PT) index allowed a comparison of the frequency of application of HRAC groups and active substances by farmers in resistant and susceptible cornflower-infested fields despite there being a different number of identified populations susceptible and resistant to ALS inhibitors and synthetic auxins. For PT index calculation, populations were divided into susceptible or resistant in accordance with the results of biological tests in the glasshouse.

C. cyanus seeds were collected from mature plants. Where the weed was distributed uniformly along the whole field, a plot of $100 \times 50 \mathrm{~m}$ was designated. Infruitescences of C. cyanus were harvested from a few spots and combined into 1 sample in a paper bag $[28,29]$. At least 100 fully developed infruitescences were harvested in 1 field. On each occasion, the geographic coordinates of the collection place were noted.

The collected samples were stored in a ventilated, dry room until they were air-dried, and the samples were then cleaned and the paper bags with seeds were marked. In order to break dormancy, the seeds were kept in a cool room at $4{ }^{\circ} \mathrm{C}$ for 7 days [29].

\subsection{Biological Tests in Glasshouses}

Biological tests were carried out in 2018-2020 in ventilated glasshouses with a 14/10-h photoperiod during early spring and autumn and in natural sunlight from June to July. The temperature in the glasshouses ranged from 16 to $25^{\circ} \mathrm{C}$. Multipots, with a single pot of $5.5 \mathrm{~cm}$ in diameter, were filled with a mixture of commercial vegetable substrate Kronen (R) (Lasland sp. z o.o. Grądy, Poland) mixed with sand in a proportion of 2:1. A few C. cyanus seeds were sown in a single pot, and after emergence, the number of plants was regulated to 3 per pot. The experimental layout was a complete randomised design with 3 replicates per dose. 
The resistance/susceptibility of C. cyanus was tested against 4 post-emergent herbicides (Table 1).

Table 1. Description of herbicides used in the biological tests.

\begin{tabular}{ccccc}
\hline Active Substance & Commercial Product & $\begin{array}{c}\text { Content of Active Substance } \\
\text { In Commercial Products }\end{array}$ & Producer & $\begin{array}{c}\text { Field Dose (N1) of } \\
\text { Active Substance }\end{array}$ \\
\hline Tribenuron-methyl & Lumer 500 WG & $500 \mathrm{~g} \mathrm{~kg}^{-1}$ & ADAMA, PL & $15 \mathrm{~g} \mathrm{ha}^{-1}$ \\
Florasulam & Saracen 050 SC & $50 \mathrm{~g} \mathrm{~L}^{-1}$ & Cheminova, PL & $5 \mathrm{~g} \mathrm{ha}^{-1}$ \\
$2,4-\mathrm{D}$ & Aminopielik Standard & $600 \mathrm{~g} \mathrm{~L}^{-1}$ & ADAMA, PL & $750 \mathrm{~g} \mathrm{ha}^{-1}$ \\
Dicamba & 600 SL & $480 \mathrm{~g} \mathrm{~L}^{-1}$ & Sharda, PL & $288 \mathrm{~g} \mathrm{ha}^{-1}$ \\
\hline
\end{tabular}

Distilled water solutions of the hserbicides $(100 \mathrm{~mL})$ were prepared using the dilution method, where the highest dose of herbicide (32 times the field dose) was a stock solution.

The herbicides were applied using 2 precision bench sprayers (FHU KAMA, SkarżyskoKamienna, PL and APORO Sp. z o.o., Poznań, Poland), each with a boom equipped with one flat-fan hydraulic Teejet XR 11002 VP nozzle, and calibrated to the same parameters, i.e., delivering $200 \mathrm{~L} \mathrm{ha}^{-1}$ of spray at a pressure of 200 bars.

\subsubsection{Discriminate Dose Experiments}

This test was performed to verify whether the collected C. cyanus populations were herbicide-resistant. Plants in the 2-leaf stage, BBCH 12 [30], were sprayed with a field dose (N1) of herbicide and with distilled water (a control treatment).

The visual estimated biomass (VEB) reduction on a scale of $0-100 \%$ was assessed 3 weeks after spraying [29]. Plants were assessed as susceptible at VEB $=51-100 \%$ ). Plants at $\mathrm{VEB} \leq 50 \%$ were classified as potentially resistant and qualified for whole-plant doseresponse bioassays.

\subsubsection{Whole-Plant Dose-Response Bioassays}

At the 2-leaf growth stage BBCH 12 [30], potentially resistant C. cyanus plants were sprayed with 1 of 7 doses of herbicide: N1/2, N1, N2, N4, N8, N16 or N32, where N refers to the field dose. Each time, susceptible populations representative of the Polish region was taken for comparison and were also sprayed with the following herbicide doses: N1/16, $\mathrm{N} 1 / 8, \mathrm{~N} 1 / 4, \mathrm{~N} 1 / 2, \mathrm{~N} 1, \mathrm{~N} 2$ and N4. Control plants were sprayed with distilled water only (N0).

Three weeks after herbicide application, the aboveground plant biomass was cut and immediately weighed (fresh biomass) using a laboratory balance (Radwag, Radom, Poland) with an accuracy of 3 decimal places.

The aim of the whole-plant dose-response bioassay was to establish the ED50 dose, i.e., the dose causing a 50\% reduction in the biomass of a herbicide-treated plant. ED50 was calculated using the 'drc' package [31] in R ver. 4.0.1 [32]. Dose-response curves were plotted using a logarithmic scale for herbicide dose (X-axis).

For ED50 calculations, as a reference value for the susceptible populations (S) the mean values from different $C$. cyanus populations were taken from 7 populations for ALS inhibitors, 3 populations for dicamba and $1 \mathrm{~S}$ population for 2,4-D. The calculated values were close to a half dose of each of the herbicides, namely $6.72 \mathrm{~g} \mathrm{ha}^{-1}$ for tribenuron, $2.24 \mathrm{~g} \mathrm{ha}^{-1}$ for florasulam, $268 \mathrm{~g} \mathrm{ha}^{-1}$ for 2,4-D and $150.18 \mathrm{~g} \mathrm{ha}^{-1}$ for dicamba.

The resistance index (RI) classification was based on the modified scale of Beckie and Tardif [33] for ALS inhibitors. The RI index [30], defined as an effective herbicide dose reducing growth or survival by 50\% compared with the untreated control (ED50) of the resistant population compared with the susceptible population, was: S-susceptibility $(<2)$; $\mathrm{r}$-reduced susceptibility (2-2.9); R-low resistance (3-5); RR-moderate resistance (6-10); RRR—high resistance (11-71.4); RRRR—very high resistance (>71.4). 


\section{Results}

3.1. Survey-Based Short-Time Herbicide Treatment History of Herbicide-Resistant and Susceptible C. cyanus in Poland

Mouldboard ploughing and no-plough tillage (type of the cultivation of the soil where the plow is replaced with tools which don't reverse the soil, such as: cultivator, gruber, harrow, disc harrow, rotary cultivator) were performed every year for three consecutive years in 64 and 19 of 83 fields with herbicide-resistant cornflower, constituting 77\% and $23 \%$ of these fields, respectively (Figure 1a). Similar proportions for the tillage systems used were found in fields with susceptible cornflower populations (Figure 1b). The crop structure for the resistant populations was dominated by winter crops, which constituted $81 \%$ of all crops. Winter wheat, winter oilseed rape and winter triticale dominated the structure, constituting $45 \%, 21 \%$ and $12 \%$ of the crops (Figure 1c). In the crop structure for susceptible cornflower populations, the share of spring plants was higher by $5 \%$ compared to resistant populations. The winter plants also dominated in these fields, but winter wheat and winter triticale had a smaller share (Figure 1d).

a

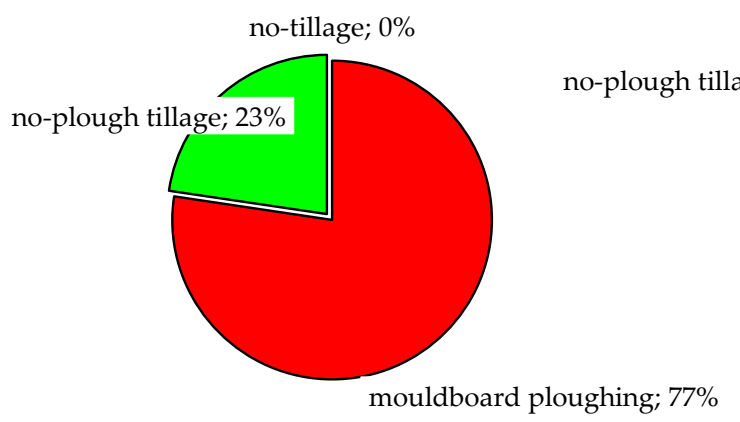

$\mathrm{b}$

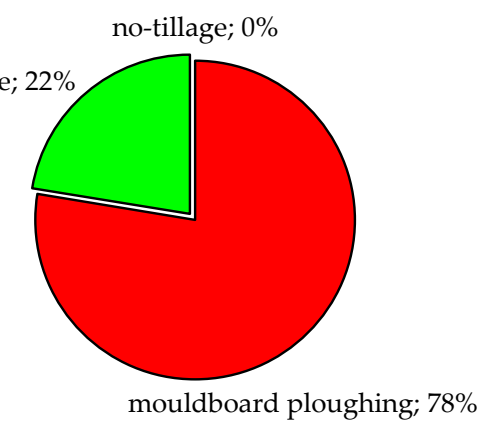

C

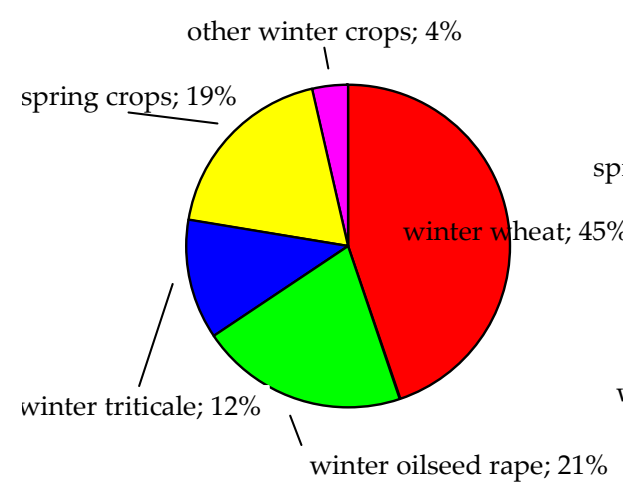

d

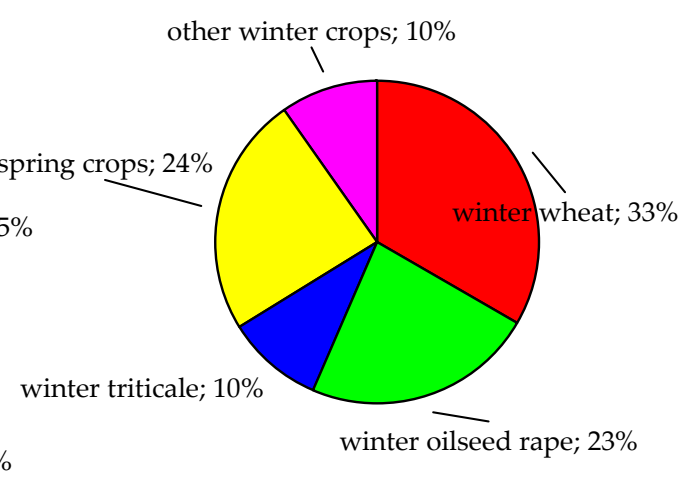

Figure 1. Structure of the tillage systems $(\mathbf{a}, \mathbf{b})$ and cultivated plants $(\mathbf{c}, \mathbf{d})$ in crop fields with herbicideresistant $(\mathbf{a}, \mathbf{c})$ and susceptible $(\mathbf{b}, \mathbf{d})$ populations of Centaurea cyanus $\mathrm{L}$. in two or three successive growing seasons.

Populations of herbicide-resistant cornflower were mainly found in winter cereals. Of 83 populations where resistance to herbicides was confirmed, 51 were found in winter wheat. Of these, one population was resistant to ALS inhibitors and had reduced sensitivity to synthetic auxins, 30 populations were resistant to tribenuron and florasulam, 16 were resistant only to tribenuron and 4 to just florasulam. Furthermore, 13 populations were found in winter triticale, 8 in winter oilseed rape, 5 in legumes, and 6 in other cultivated grasses (oats, barley, rye or perennial ryegrass). 
The analysis of the two or three-year history of chemical weed control of cornflower in Poland showed that for each herbicide-resistant population during the time analysed, 4.78 different active substances (population treatments $=\mathrm{PT}$ ) were used on average. In the fields with susceptible cornflower populations, PT was the lowest and amounted to 3.97 on average. The highest frequency of herbicide use was in fields with C. cyanus populations resistant to tribenuron and florasulam where PT was 5.85 (Table 2). Among provinces analysed in Poland the frequency of herbicide application was the greatest in Warmia-Masuria Province (PT = 7.4).

Table 2. Population treatment (PT) of the herbicide active ingredient in crop fields with Centaurea cyanus populations resistant to acetolactate synthase inhibitors (HRAC 2) ( $r$ and R) and susceptible (S) in two or three successive growing seasons.

\begin{tabular}{|c|c|c|c|c|c|}
\hline HRAC & Active Ingredient & $\mathrm{T}+\mathrm{F}$ & $\mathbf{T}$ & $\mathbf{F}$ & $S$ \\
\hline \multirow{11}{*}{2} & florasulam & 0.70 & 0.57 & 0.25 & 0.45 \\
\hline & tribenuron-methyl & 0.49 & 0.39 & 0.50 & 0.38 \\
\hline & metsulfuron-methyl & 0.38 & 0.18 & & 0.11 \\
\hline & chlorsulfuron & 0.30 & 0.14 & 0.25 & 0.18 \\
\hline & iodosulfuron-methyl-Na & 0.32 & 0.18 & 0.13 & 0.16 \\
\hline & thifensulfuron-methyl & 0.21 & 0.18 & & 0.04 \\
\hline & thiencarbazone-methyl & 0.11 & 0.11 & 0.13 & 0.07 \\
\hline & sulfosulfuron & 0.04 & & & \\
\hline & flupyrsulfuron-methyl & 0.02 & & & 0.05 \\
\hline & triasulfuron & 0.02 & 0.11 & & \\
\hline & Total & 2.59 & 1.86 & 1.26 & 1.44 \\
\hline \multirow{6}{*}{5} & metribuzin & 0.28 & 0.25 & 0.26 & 0.30 \\
\hline & metamitron & 0.02 & & & \\
\hline & terbuthylazine & & 0.07 & & 0.03 \\
\hline & chlorotoluron & 0.26 & 0.29 & 0.12 & 0.24 \\
\hline & isoproturon & 0.21 & 0.04 & & 0.04 \\
\hline & Total & 0.77 & 0.65 & 0.38 & 0.61 \\
\hline 6 & bromoxynil & & 0.04 & & \\
\hline 12 & diflufenican & 0.62 & 0.68 & 0.50 & 0.54 \\
\hline 9 & glyphosate & 0.02 & & & 0.05 \\
\hline 3 & pendimethalin & 0.19 & 0.07 & & 0.12 \\
\hline \multirow{9}{*}{4} & $2,4 \mathrm{D}$ & 0.51 & 0.21 & 0.12 & 0.32 \\
\hline & aminopyralid & 0.49 & 0.43 & 0.75 & 0.37 \\
\hline & clopyralid & 0.11 & 0.04 & 0.63 & 0.13 \\
\hline & dicamba & 0.09 & 0.07 & & 0.05 \\
\hline & fluroxypyr & 0.28 & 0.07 & & 0.16 \\
\hline & MCPA & 0.09 & 0.07 & & 0.09 \\
\hline & $\mathrm{MCPB}$ & & & & 0.01 \\
\hline & picloram & 0.09 & 0.04 & 0.63 & 0.08 \\
\hline & Total & 1.66 & 0.93 & 2.13 & 1.21 \\
\hline \multicolumn{2}{|c|}{ Mean for populations } & 5.85 & 4.23 & 4.27 & 3.97 \\
\hline \multicolumn{2}{|c|}{ Number of populations } & 47 & 28 & 8 & 76 \\
\hline $\mathrm{PT}=$ & $0.20-0.39$ & \multicolumn{2}{|c|}{$0.40-0.59$} & \multicolumn{2}{|c|}{$0.60-0.79$} \\
\hline
\end{tabular}

$\mathrm{T}+\mathrm{F}$-resistant to tribenuron-methyl and florasulam; T—resistant to tribenuron-methyl; F-resistant to florasulam; S-susceptible to all active ingredients tested during biological tests in the glasshouse; HRAC - Herbicide Resistance Action Committee 
In the fields infested with cornflower resistant to tribenuron and florasulam, the most commonly used herbicides per resistant population were ALS inhibitors (HRAC 2) (Table 2). In the fields with C. cyanus resistant to both active ingredients (tribenuron and florasulam), active substances from the ALS inhibitor group were used at an average frequency of $\mathrm{PT}=2.59$. A lower frequency of ALS inhibitor application was found in fields containing cornflower with single herbicide resistance. Specifically, in the fields with populations resistant to tribenuron, the PT of HRAC 2 was 1.86, whereas in fields with resistance to florasulam the PT was 1.26. PT for ALS inhibitor for susceptible populations was 1.44. Among the active substances from the ALS inhibitor group, florasulam was used most often and its PT ranged from 0.25 to 0.70 for resistant populations and 0.45 for susceptible. Tribenuron-methyl was used less frequently, with PT from 0.38 to 0.50 . In fields with cornflower populations with single resistance to florasulam, the dominant group of herbicides was synthetic auxins (HRAC 4), with a PT of 2.13. In crops with cornflower that was cross-resistant to tribenuron and florasulam, the PT for HRAC 4 was 0.47 lower than for the fields with cornflower resistant to florasulam only. In fields where cornflower populations resistant to tribenuron were identified, the PT for HRAC 4 was 0.93. In fields with cornflower that were cross-resistant or showed single resistance to tribenuron, seven different herbicides from the groups of synthetic auxins and auxin transport inhibitors were used. Among them, 2.4 D and aminopyralid were the most frequently used in fields with cross-resistance, its PT was 0.51 and 0.49 , respectively. In the fields with single resistance to tribenuron or florasulam, aminopyralid was used most frequently. In crops infested with susceptible populations of cornflower PT for 2.4 D and aminopyralid was 0.32 and 0.37, respectively. Moreover, diflufenican (HRAC 12) was often used by farmers; its PT ranged from 0.60 to 0.79 in fields with cross-resistance and tribenuron resistance, and from 0.40 to 0.59 in fields with florasulam-resistant and susceptible cornflower.

Despite only identifying three populations of $C$. cyanus resistant to synthetic auxins (HRAC 4), the surveys highlighted some trends in farmers' use of active ingredients in these fields. The most commonly used herbicides were synthetic auxins and ALS inhibitors. Two herbicides were applied from the HRAC 4 group: aminopyralid $(\mathrm{PT}=1)$ and 2,4-D $(\mathrm{PT}=1)$. Among the ALS inhibitors, florasulam was most frequently used $(\mathrm{PT}=1)$. Chlorotoluron, a urea derivative from the HRAC 5 group, was also used with the same frequency $(\mathrm{PT}=1)$.

\subsection{Distribution and Resistance Index of Herbicide-Resistant Cornflower Populations in Poland}

The reaction of cornflower populations in the whole-plant dose-response bioassays to herbicides varied (Tables 3 and 4). A total of 83 out of 159 populations showed resistance to at least one active ingredient. In the case of C. cyanus resistant to ALS inhibitors, based on ED50 values, the ED50 $/ E D 50_{S}$ ratio ranged from 2.0-fold to over 71.4-fold for both tribenuron-methyl and florasulam. Resistance and reduced susceptibility ( $\mathrm{r}$ ) to tribenuron-methyl was found in 75 out of 83 populations. The majority of tribenuronresistant populations (59 out of 75) showed high or very high levels of resistance. A total of 55 out of 83 populations were found to be resistant to florasulam, most (32 out of 55) at a level of high or very high resistance, with ED50 $/ \mathrm{RD} 50_{\mathrm{S}}$ ratios in a range of 11.6-fold to over 71.4-fold. There were 47 populations diagnosed as cross-resistant to both tribenuron and florasulam. Within this group, 26 out of 47 populations showed high or very high levels of resistance to both ALS inhibitors. There were 28 populations resistant to tribenuron-methyl only, while 8 populations were found to be resistant to florasulam only. 
Table 3. Populations of cornflower resistant to acetolactate synthase inhibitors characterised by ED50 (effective dose causing $50 \%$ shoot fresh weight reduction in the treated plants) and resistance index (RI).

\begin{tabular}{|c|c|c|c|c|c|}
\hline \multirow{2}{*}{ Population } & \multirow{2}{*}{ Province } & \multicolumn{2}{|c|}{ Tribenuron-Methyl } & \multicolumn{2}{|c|}{ Florasulam } \\
\hline & & RI & ED50 (g ha $\left.{ }^{-1}\right)$ & RI & ED50 $\left(\mathrm{g} \mathrm{ha}^{-1}\right)$ \\
\hline 8818 & GP & $S$ & $\mathrm{X}$ & RRR & 27.3 \\
\hline 8551 & KP & RRR & 90.0 & $\mathrm{~S}$ & $x$ \\
\hline 9263 & KP & $\mathrm{RR}$ & 45.0 & $\mathrm{~S}$ & $x$ \\
\hline 9264 & KP & $\mathrm{R}$ & 30.0 & $S$ & $x$ \\
\hline 9334 & KP & $\mathrm{R}$ & 35.0 & S & $x$ \\
\hline 9339 & KP & $\mathrm{RR}$ & 55.0 & $\mathrm{r}$ & 4.5 \\
\hline 9347 & KP & $\mathrm{RR}$ & 40.0 & S & $x$ \\
\hline 9586 & LP & $\mathrm{S}$ & $\mathrm{X}$ & $\mathrm{R}$ & 9.0 \\
\hline 9624 & LP & S & $x$ & $\mathrm{r}$ & 4.7 \\
\hline 9632 & LP & S & $x$ & $\mathrm{R}$ & 9.6 \\
\hline 8920 & LP & S & $\mathrm{X}$ & RRR & 60.5 \\
\hline 8924 & LP & RRRR & $>480$ & RRRR & $>160$ \\
\hline 8925 & LP & S & $x$ & RRRR & $>160$ \\
\hline 8948 & LP & RRRR & $>480$ & RRR & 80.5 \\
\hline 9012 & LP & RRRR & $>480$ & RRR & 46.9 \\
\hline 9015 & LP & RRRR & $>480$ & $\mathrm{~S}$ & $x$ \\
\hline 9017 & LP & RRRR & $>480$ & RRR & 95.1 \\
\hline 9025 & LP & RRRR & $>480$ & S & $X$ \\
\hline 9028 & LP & RRRR & $>480$ & $\mathrm{R}$ & 11.4 \\
\hline 9030 & LP & RRRR & $>480$ & $\mathrm{~S}$ & $X$ \\
\hline 8413 & $\mathrm{Lb}$ & RRR & 80.8 & RRR & 27.7 \\
\hline 8486 & $\mathrm{Lb}$ & RRR & 374.1 & $\mathrm{~S}$ & $x$ \\
\hline 8492 & $\mathrm{Lb}$ & RRR & 277.3 & RR & 14.6 \\
\hline 8494 & $\mathrm{Lb}$ & RRR & 89.3 & $\mathrm{RR}$ & 14.0 \\
\hline 8512 & $\mathrm{Lb}$ & RRR & 108.2 & $\mathrm{RR}$ & 22.8 \\
\hline 8516 & $\mathrm{Lb}$ & RRR & 148.6 & RRR & 60.4 \\
\hline 8524 & $\mathrm{Lb}$ & RRR & 119.7 & RRR & 27.2 \\
\hline 8717 & $\mathrm{Lb}$ & RRR & 131.7 & $\mathrm{RR}$ & 13.7 \\
\hline 8726 & $\mathrm{Lb}$ & RRRR & $>480$ & RRR & 34.3 \\
\hline 8729 & $\mathrm{Lb}$ & RRRR & $>480$ & RRR & 51.8 \\
\hline 8734 & $\mathrm{Lb}$ & RRR & 281.7 & RRR & 45.0 \\
\hline 9414 & $\mathrm{Lb}$ & RRR & 101.6 & $\mathrm{R}$ & 7.2 \\
\hline 10111 & Ms & $\mathrm{RR}$ & 43.0 & $\mathrm{RR}$ & 17.0 \\
\hline 9302 & $\mathrm{Pd}$ & RRR & 158.7 & RRR & 49.4 \\
\hline 9303 & $\mathrm{Pd}$ & RRR & 229.5 & RRR & 136.4 \\
\hline 9306 & $\mathrm{Pd}$ & RRR & 201.8 & RRR & 99.1 \\
\hline 9307 & $\mathrm{Pd}$ & RRR & 151.0 & RRR & 76.6 \\
\hline 9309 & $\mathrm{Pd}$ & $\mathrm{RR}$ & 50.6 & RRR & 57.7 \\
\hline 9400 & $\mathrm{Pd}$ & RRR & 89.0 & $\mathrm{R}$ & 7.8 \\
\hline 9402 & $\mathrm{Pd}$ & RRR & 281.6 & RRR & 50.4 \\
\hline 10264 & $\mathrm{Pd}$ & RRR & 88.8 & S & $x$ \\
\hline 9240 & $\mathrm{Pm}$ & $\mathrm{RR}$ & 60.0 & S & $x$ \\
\hline 9247 & $\mathrm{Pm}$ & RRR & 155.0 & S & $x$ \\
\hline 9249 & $\mathrm{Pm}$ & $\mathrm{RR}$ & 54.0 & $S$ & $x$ \\
\hline
\end{tabular}


Table 3. Cont.

\begin{tabular}{|c|c|c|c|c|c|}
\hline \multirow{2}{*}{ Population } & \multirow{2}{*}{ Province } & \multicolumn{2}{|c|}{ Tribenuron-Methyl } & \multicolumn{2}{|c|}{ Florasulam } \\
\hline & & RI & ED50 (g ha $\left.{ }^{-1}\right)$ & RI & $\operatorname{ED} 50\left(\mathrm{~g} \mathrm{ha}^{-1}\right)$ \\
\hline 9251 & $\mathrm{Pm}$ & RR & 65.0 & S & $x$ \\
\hline 9256 & Pm & RRR & 90.0 & $S$ & $x$ \\
\hline 9655 & Pm & RRRR & $>480$ & $\mathrm{R}$ & 6.8 \\
\hline 10298 & $\mathrm{Pm}$ & RRRR & $>480$ & RR & 21.0 \\
\hline 10356 & $\mathrm{Sb}$ & RRR & 77.3 & $\mathrm{~S}$ & $X$ \\
\hline 8834 & Św & S & $X$ & $\mathrm{R}$ & 7.9 \\
\hline 9597 & Sw & $\mathrm{R}$ & 30.9 & S & $X$ \\
\hline 9622 & Sw & $S$ & $X$ & RRR & 37.9 \\
\hline 10289 & Św & RRR & 75.6 & S & $x$ \\
\hline 10293 & Św & $\mathrm{r}$ & 13.5 & $S$ & $x$ \\
\hline 10339 & Sw & RRR & 153.6 & $S$ & $x$ \\
\hline 10345 & Sw & RRR & 109.3 & $S$ & $x$ \\
\hline 10348 & Sw & RRR & 127.9 & $S$ & $X$ \\
\hline 8401 & WM & RRR & 259.7 & RRR & 43.5 \\
\hline 8402 & WM & RRR & 155.4 & RRR & 101.9 \\
\hline 8405 & WM & RRR & 111.1 & RRR & 25.9 \\
\hline 8406 & WM & RRR & 302.0 & RRR & 29.3 \\
\hline 8537 & WM & RRR & 320.0 & $\mathrm{R}$ & 10.0 \\
\hline 8738 & WM & RRRR & $>480$ & RRR & 40.3 \\
\hline 8743 & WM & RRRR & $>480$ & RRR & 51.8 \\
\hline 8748 & WM & RRRR & $>480$ & RRR & 48.9 \\
\hline 8794 & WM & $\mathrm{R}$ & 27.6 & S & $X$ \\
\hline 8798 & WM & $\mathrm{R}$ & 39.2 & RRR & 35.0 \\
\hline 8821 & WM & RRRR & $>480$ & S & $x$ \\
\hline 9258 & WM & RRR & 85.0 & $r$ & 5.0 \\
\hline 9260 & WM & $\mathrm{RR}$ & 60.0 & $\mathrm{r}$ & 5.0 \\
\hline 9380 & WM & RRR & 117.3 & $\mathrm{R}$ & 11.3 \\
\hline 9661 & WM & RRRR & $>480$ & $S$ & $x$ \\
\hline 10280 & WM & RRRR & $>480$ & S & $X$ \\
\hline 10370 & WM & RRRR & $>480$ & RRR & 54.0 \\
\hline 8972 & WP & RRRR & $>480$ & $\mathrm{RR}$ & 17.1 \\
\hline 10301 & WP & RRRR & $>480$ & $\mathrm{R}$ & 10.8 \\
\hline 10302 & WP & $\mathrm{R}$ & 29.5 & $S$ & $X$ \\
\hline 10304 & WP & RRRR & $>480$ & RRR & 48.5 \\
\hline 10309 & WP & RRR & 320.4 & $\mathrm{R}$ & 7.1 \\
\hline 10317 & WP & RRRR & $>480$ & $\mathrm{R}$ & 9.6 \\
\hline 10318 & WP & RRR & 149.7 & RRR & 26.7 \\
\hline 10327 & WP & RRR & 118.6 & RRR & 26.5 \\
\hline 10333 & WP & RRRR & $>480$ & S & $X$ \\
\hline
\end{tabular}

RI (resistance index) on the basis of ED50 $/$ /ED50 value: $\mathrm{S}=$ susceptibility $(<2) ; \mathrm{r}=$ reduced susceptibility $(2-2.9) ; \mathrm{R}=$ low resistance (3-5); $\mathrm{RR}=$ moderate resistance (6-10); RRR = high resistance (11-71.4); RRRR = very high resistance (>71.4) (the modified scale of Beckie and Tardiff, 2012); X-ED50 was not calculated because populations qualified as susceptible in discriminate dose experiments were not subjected to whole-plant dose-response bioassays. Abbreviations: GP—Greater Poland; KP—Kuyavia-Pomerania; LP—Lesser Poland; LS—Lower Silesia; Lb—Lublin; Ms—Masovia; Pd-Podlasie; Pm—Pomerania; Sb—Subcarpathia; Św—Świętokrzyskie; WM-Warmia-Masuria; WP-West Pomerania. 
Table 4. Populations of cornflower resistant to synthetic auxins characterised by ED50 (effective dose causing 50\% shoot fresh weight reduction in the treated plants) and resistance index (RI).

\begin{tabular}{|c|c|c|c|c|c|}
\hline \multirow{2}{*}{ Biotype } & \multirow{2}{*}{ Province } & \multicolumn{2}{|c|}{ Dicamba } & \multicolumn{2}{|c|}{ 2,4-D } \\
\hline & & RI & ED50 (g ha $\left.{ }^{-1}\right)$ & RI & $\operatorname{ED50}\left(\mathrm{g} \mathrm{ha}^{-1}\right)$ \\
\hline 8486 & $\mathrm{Lb}$ & $\mathrm{r}$ & 397.5 & $\mathrm{r}$ & 696 \\
\hline 9400 & $\mathrm{Pd}$ & $\mathrm{r}$ & 334.34 & $\mathrm{r}$ & 732 \\
\hline 9380 & WM & $\mathrm{R}$ & 583.8 & $\mathrm{r}$ & 750 \\
\hline
\end{tabular}

RI (resistance index) on the basis of ED50 $/$ ED50s value: $\mathrm{S}=$ susceptibility $(<2) ; \mathrm{r}=$ reduced susceptibility $(2-2.9)$ $\mathrm{R}=$ low resistance (3-5); $\mathrm{RR}=$ moderate resistance (6-10); $R R R=$ high resistance (11-71.4); $R R R R=$ very high resistance (>71.4) (the modified scale of Beckie and Tardiff, 2012). Abbreviations: Lb—Lublin; Pd—Podlasie; WM-Warmia-Masuria.

Most of the populations resistant to ALS inhibitors (17, equal to $20 \%$ of all resistant populations) were found in Warmia-Masuria Province (north-east Poland) (Table 3). Over $82 \%$ of the populations from this province displayed high or very high levels of resistance to tribenuron methyl. Moreover, nearly half of the populations from this region $(47 \%)$ showed high or very high resistance to both ALS inhibitors tested. Several resistant populations were also found in the provinces of Lublin, Lower Silesia and West Pomerania (12, 10 and 9 populations, respectively). All populations from Lublin Province showed high or very high levels of resistance to tribenuron, and 50\% were at least highly resistant to both ALS inhibitors. In Lower Silesia Province, $50 \%$ of the populations there had high or very high resistance to both ALS and very high resistance to tribenuron ( $80 \%$ of populations). In West Pomeranian Province, eight out of nine populations had high or very high tribenuron resistance, and three populations had at least high resistance to both ALS.

The distribution of locations where herbicide-resistant populations of $C$. cyanus were found is presented in Figure 2.

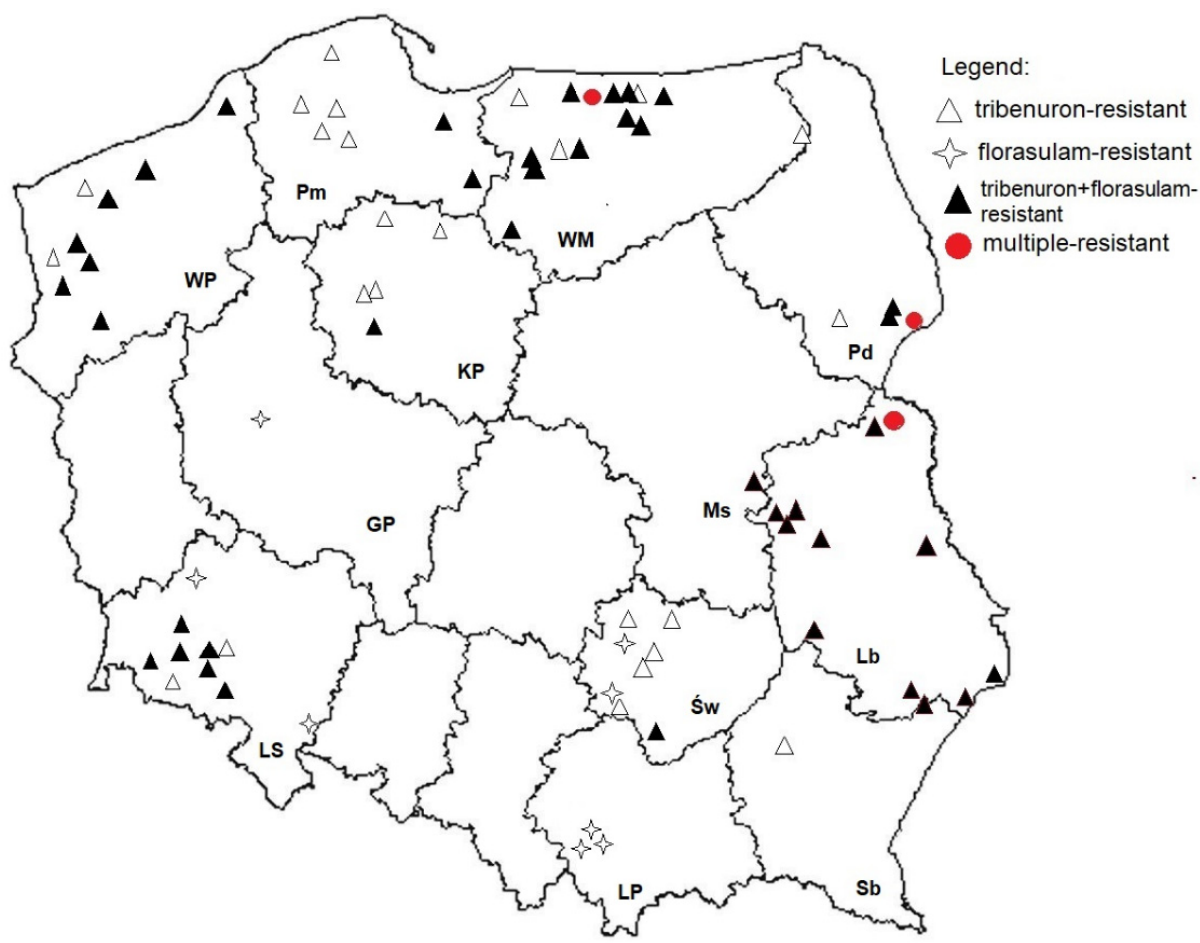

Figure 2. Locations in Poland where herbicide-resistant populations of Centaurea cyanus L. were found. Abbreviations: GP-Greater Poland; KP-Kuyavia-Pomerania; LP—Lesser Poland; LSLower Silesia; Lb—Lublin; Ms—Masovia; Pd-Podlasie; Pm-Pomerania; Sb-Subcarpathia; Św— Świętokrzyskie; WM-Warmia-Masuria; WP-West Pomerania. 
The C. cyanus populations were also tested for their sensitivity to auxinic herbicides. Most populations were found to be susceptible to dicamba, but two populations, 8486 and 9400, showed reduced sensitivity (r) and one population, 9380, showed a low level of dicamba resistance. Their reaction to dicamba was 2.2-fold to 3.9-fold weaker than that of the reference susceptible populations (Table 4 and Figure 3). Their ED50 was compared to $150 \mathrm{~g}$ a.i. $\mathrm{ha}^{-1}$, the mean ED50 value of three reference susceptible biotypes (Figure 3)

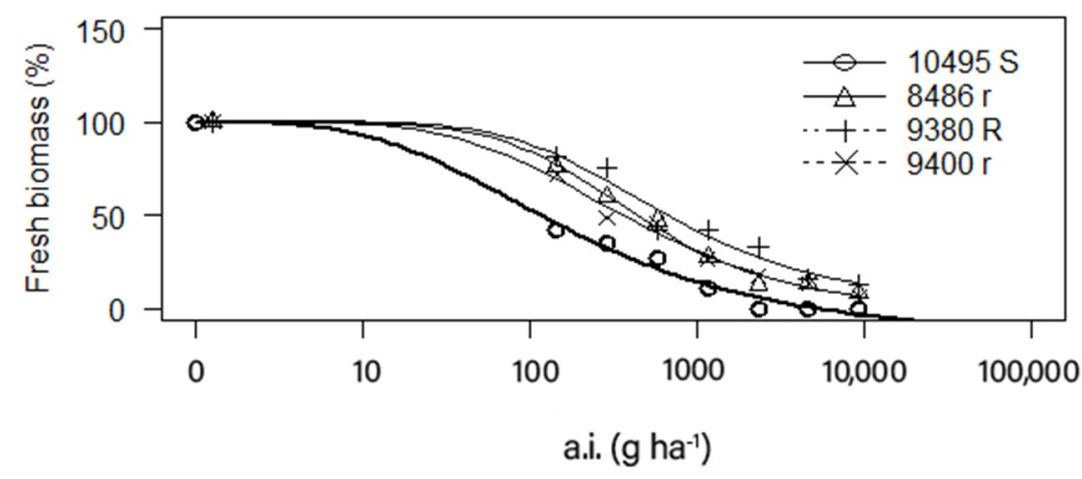

Figure 3. Dose-response curves of Centaurea cyanus population resistant (R), with reduced susceptibility (r) and susceptible (S) to dicamba.

A comparison of the reaction of the susceptible population with that of the population with reduced susceptibility to dicamba is shown in Figure S1.

The populations with reduced sensitivity to dicamba were also submitted to the whole-plant dose-response test to 2,4-D. As shown by the dose-response curves in Figure 4, their sensitivity to 2,4-D was also reduced. Their ED50 was 2.6-fold to 2.8-fold lower than the ED50 of the reference susceptible population (286 $\mathrm{g}$ a.i. ha ${ }^{-1}$ ) (Table 4 and Figure 4 ).

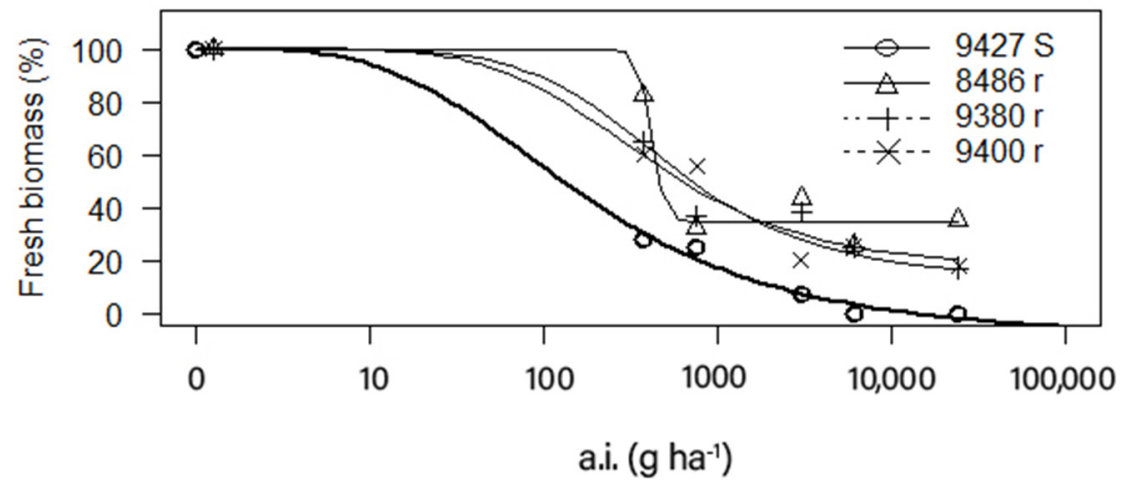

Figure 4. Dose-response curves of Centaurea cyanus populations with reduced susceptibility (r) and susceptible (S) to 2,4-D.

The different susceptibilities of cornflower populations to 2,4-D are demonstrated in Figure S2.

The populations of cornflower with a low level of resistance or reduced susceptibility to auxinic herbicides, i.e., 8486, 9380 and 9400, exhibited high levels of resistance to tribenuron methyl $\left(\mathrm{ED} 0_{\mathrm{R}} / \mathrm{ED} 0_{\mathrm{S}}\right.$ ratio $=55.7,13.2$ and 17.5 respectively) and two of them showed a low level of resistance to florasulam $\left(E D 50_{R} / E D 50_{S}\right.$ ratio $=3.5$ and 5.0) (Tables 3 and 4).

\section{Discussion}

As the present study shows, the issue of cornflower resistance to ALS inhibitors is increasingly being found. In Poland, this group of herbicides currently plays a crucial role in the chemical weed control of winter cereals. Sulfonylurea derivatives, such as tribenuron 
methyl, chlorsulfuron, mezosulfuron + iodosulfuron and iodosulfuron, have been used for years for weed control in winter cereal cultivation [5].

More than half of the cornflower populations analysed in this study were found to be resistant to ALS inhibitors. Based on the information provided by farmers, cornflower populations resistant to tribenuron methyl, florasulam or both were found in 12 provinces in Poland. The most frequent problems with the efficacy of cornflower control were indicated in Warmia-Masuria Province (17 out of 83 resistant populations). The provinces of Lublin and Lower Silesia were second and third in terms of the number of cornflower populations resistant to ALS inhibitors highlighted by farmers and confirmed by biological tests.

In two of these regions, Lower Silesia and Warmia-Masuria, issues with cornflower resistance to ALS inhibitors were first reported in 2006 [20] and 2010 [21], respectively. The provinces of Warmia-Masuria, Lublin and Lower Silesia are also regions in Poland where herbicide-resistant populations of other weed species in winter cereal fields have been found, such as A. spica venti or A. myosuroides [34-37]. According to a study by Adamczewski et al. [25] undertaken in Poland over a 14-year period (2004-2017), A. spica-venti populations resistant to ALS inhibitors were found in over $50 \%$ of fields. Adamczewski et al. [25] suggested that such a high number of fields with populations resistant to sulfonylureas, especially to chlorsulfuron, was probably because farmers in Poland had been using this active ingredient for years to control weeds because it was cheap. Such selection pressure in the past could also be a reason for the present situation concerning the ALS resistance of C. cyanus in Poland.

The present research showed that on the farms surveyed in Warmia-Masuria Province, the frequency of herbicide application was greater than in the other provinces. Intense herbicide use can be justified where high levels of susceptibility remain in the weed population. However, as shown by the study of Varah et al. [38], in fields with high levels of herbicide resistance, intense herbicide application may be counterproductive because the costs of the herbicide will outweigh the benefits of weed control. Moreover, it can have the undesired effect of selecting for even greater frequencies of resistance within populations [39]. Warmia-Masuria Province could be a good example of such unwanted selection. The problem with cornflower control was first reported here in 2010, and the present study conducted in 2017-2020 showed that the situation in this region had worsened, with resistant populations in this region very often showing high or very high levels of ALS resistance.

In the present study, populations of cornflower resistant to herbicides were found in regions such as Warmia-Masuria and Lower Silesia where, according to Rozkrut [40], the average area of a farm was 23.5 ha and 17.29 ha, respectively, which was greater than the national average (11.04 ha), but also in provinces where smaller farms dominate, such as Lublin or Świętokrzyskie Provinces. The average area of a farm in Lublin and Świętokrzyskie Provinces is 7.98 ha and 5.88 ha, respectively. This finding is supported by the results of other researchers who state that cultural practices are more important for a risk assessment of herbicide resistance than the region's agrarian structure [5,41]. Most fields in which resistant and susceptible populations of cornflower were found were mouldboard ploughed. This type of soil cultivation contributes to the reduction of the population of many weeds, including herbicide-resistant populations [42]. However, according to Moss et al. [41], the impact of mouldboard ploughing in weed control depends on the weed species and is probably more important for monocotyledonous weeds. In contrast, in the case of herbicide-resistant $P$. rhoeas, a dicotyledonous weed with a growth pattern similar to cornflower, the method of soil tillage-intensive or direct drilling-does not change the frequency of resistant plants [43]. Wheat monocultures or simplified crop rotations, based mainly on winter crops, dominated in the rotation history of the fields with herbicide resistant populations in the present study. Most cornflower-resistant populations originated from winter wheat, winter triticale and winter oilseed rape that were also cultivated most frequently. In the fields with susceptible populations, farmers cultivated more spring crops and less winter wheat and winter triticale. The results of the present study confirm the 
conclusions of other researchers that narrow crop rotation exacerbates the issue of herbicideresistant weeds $[25,44]$. Crop rotations, especially with spring crops included, are often very effective tools for resistance management $[5,38,45]$, and diversification of sowing/planting date is more effective than increasing the number of crop species [46]. Despite the effect of soil tillage in reducing weed infestations, conventional tillage used in monocropping systems is still insufficient to avoid the risk of the occurrence of herbicide resistance. Under conventional tillage, a percentage of winter crops in the rotation exceeding $75 \%$ results in a 1280-times greater risk of resistance selection compared to rotations with less than $50 \%$ winter crops [47]. Crop diversity was also recommended by Beckie and Harker [48] as the most important practice for reducing the risk of herbicide resistance in weeds.

According to the survey of farmers, the lowest herbicide use was found in fields with susceptible cornflower. Most herbicides were used by farmers to control populations with cross-resistance to both tribenuron and florasulam. ALS inhibitors and synthetic auxins were the active ingredients most frequently used for cornflower control. Herbicides from these groups were commonly applied for weed control in wheat $[5,48]$. According to Ngow et al. [49], synthetic auxins were used most frequently in weed control in cereals. However, despite their frequent use in cereals, active substances from this group cause relatively little resistance, and they are included in the group of medium risk resistance [41]. This thesis is supported by the results obtained in the present study. According to the survey of farmers, synthetic auxins were frequently used for weed control, but only one population with a low level of resistance and two populations with reduced susceptibility to this mode of action were diagnosed. In the study, herbicides from HRAC groups 4 and 12 were usually used by the farmers who must cope with cornflower with multiple resistance to ALS inhibitors and synthetic auxins. Diflufenican (HRAC 12) was the active ingredient used most frequently for cornflower resistant to ALS inhibitors. Florasulam (HRAC 2), tribenuron (HRAC 2) and aminopyralid (HRAC 4) were also often used by farmers. Diflufenican was one of the substances used most frequently in the research presented by Ngow et al. as well [49]. Considering that ALS inhibitors are among the herbicides that are very prone to resistance selection, a reduction in their use is an important recommendation [4,41]. Diflufenican is an active ingredient with a very low resistance risk, as evidenced by a very small number of populations resistant to this substance $(<1 \%$ resistance case in the world) [49]. One of the elements in herbicide resistance management (HRM) is diversity in herbicide programmes. However, as shown by the simulation undertaken by Thornby et al. [50], if the frequency of resistance genes to one herbicide (in this case glyphosate resistance) in the population is high, control with the use of three active ingredients (glyphosate, glufosinate and dicamba) may be insufficient to prevent the evolution of resistance.

Resistance to tribenuron methyl was found in the majority of cornflower populations. Cross-resistance to another ALS inhibitor, florasulam, was also diagnosed in more than a half of the tribenuron-resistant populations. Cross-resistance to other ALS inhibitors was found for C. cyanus by Adamczewski and Kierzek [21,51] in populations from three locations in Warmia-Masuria Province. The tests revealed cross-resistance patterns to sulfonylurea herbicides, i.e., tribenuron, chlorsulfuron and sulfometuron, and to an imidazolinone herbicide, i.e., imazapyr. Cross-resistance to other ALS inhibitors is commonly found in weed species $[33,52,53]$. P. rhoeas is another broadleaved weed species causing problems in winter cereals owing to herbicide resistance. Kaloumenos et al. [54] diagnosed 28 populations of this species from Greece. The whole-plant resistance factors (RFs) calculated for pyrithiobac, imazamox and florasulam ranged from 12.4 to $>88$, from 1.5 to 28.3 , and from 5.6 to 25.4 respectively, and were lower than the respective tribenuron RF values (137 to $>2400$ ). In C. cyanus, the situation in the present study was similar but there were some differences. Populations of cornflower showing high or very high resistance to both tribenuron methyl and florasulam $\left(E D 50_{R} / E D 50_{S}>71.4\right)$ were identified. There were also five cornflower populations that were highly resistant to florasulam but susceptible to tribenuron. However, in general, resistance of cornflower populations in this study was more often very high to tribenuron than to florasulam. 
In the case of three cornflower populations, development of multiple herbicide resistance across the different herbicide modes of action was diagnosed. One population from Warmia-Masuria Province was found to be highly resistant to tribenuron, but a low level of resistance to florasulam and dicamba was also diagnosed. This population also showed reduced susceptibility to 2,4-D. Two other populations with reduced susceptibility to dicamba and 2,4-D were identified in Lublin and Podlasie Provinces. They were resistant to tribenuron, but susceptible or had a low level of resistance to florasulam. Multiple herbicide resistance to ALS inhibitors and auxinic herbicides has already been identified in at least 15 weed species, including many dicotyledonous species [4]. For example, corn poppy populations with multiple resistance to ALS inhibitors and auxinic herbicides were described by Kati et al. [55], and Raphanus raphanistrum populations in Western Australian were identified by Walsh et al. [56].

Multiple resistance to ALS inhibitors and auxinic herbicides is especially dangerous because they remain pivotal herbicides for the control of many troublesome weed species in wheat and rape. The highest frequency of herbicides use in tribenuron and florasulam resistant populations was recorded for ALS inhibitors which can suggest that farmers were not aware that the cornflower herbicide resistance become more and more common in Poland, and at the beginning they attributed problems with the effectiveness of the treatment to other factors. The molecular basis of cornflower resistance to herbicides is currently being investigated and it is hoped that the results from the present study, together with the elucidation of mechanisms of cornflower resistance, will help in the elaboration of an efficient strategy for cornflower control programmes in Poland.

\section{Conclusions}

This study found that the northern and southeast regions of Poland were most affected by cornflower herbicide resistance, but several resistant populations were also found in one of the southwest provinces, Lower Silesia. Out of the 159 populations collected, 83 were diagnosed as being resistant to ALS inhibitors (tribenuron or florasulam or cross-resistant to both). Three populations developed multiple resistance to both ALS inhibitors and two synthetic auxins: 2,4-D and dicamba. The resistant populations of cornflower were most frequently collected from fields where winter cereals and mouldboard ploughing dominated. The current study shows that the domination of winter crops in crop rotations and the predominance of herbicides from the HRAC 2 and HRAC 4 groups in weed control programmes favour the selection of resistant populations even in weed species such as cornflower, which could be qualified as being at low risk of herbicide resistance.

Supplementary Materials: The following are available online at https:/ / www.mdpi.com/article/ 10.3390/agronomy11101954/s1, Figure S1: two representative populations of C. cyanus with different levels of susceptibility to dicamba: susceptibility (S) and reduced susceptibility (r). N-field dose of herbicide, Figure S2: two representative populations of $C$. cyanus with different susceptibilities to 2,4-D: susceptibility (S) and reduced susceptibility (r). N-field dose of herbicide.

Author Contributions: Conceptualisation, M.S.-K., M.H., M.W., A.S.; methodology, K.M. and K.D.; investigation, M.S.-K., M.H., M.W., A.S., A.W.-P., E.T., M.S., K.D., G.S., W.Ł., M.K., M.B. and K.M.; resources, M.S.-K., M.H., M.W., A.S., A.W.-P., E.T., M.S., K.D., G.S., W.Ł., M.K., M.B. and K.M.; data curation, M.S.-K., M.H., M.W. and A.S.; writing—original draft preparation, M.S.-K., M.H., M.W. and A.S.; writing-review and editing, M.S.-K., M.H., M.W., A.S. and G.S.; visualization, M.H., A.S. and M.S.-K.; funding acquisition, K.M. All authors have read and agreed to the published version of the manuscript.

Funding: This research was funded by The National Centre for Research and Development, contract number: BIOSTRATEG 3/347445/1/NCBR/2017.

Institutional Review Board Statement: Not applicable.

Informed Consent Statement: Not applicable. 
Data Availability Statement: The data presented in this study are available on request from the corresponding author.

Conflicts of Interest: The authors declare no conflict of interest.

\section{References}

1. Ghanizadeh, H.; Harrington, K.C. Herbicide resistant weeds in New Zealand: State of knowledge. N. Z. J. Agric. Res. 2019, 1-12. [CrossRef]

2. Ulber, L.; Rissel, D. Farmers' perspective on herbicide-resistant weeds and application of resistance management strategies: Results from a German survey. Pest Manag. Sci. 2018, 74, 2335-2345. [CrossRef] [PubMed]

3. Arslan, Z.F. Decrease in biodiversity in wheat fields due to changing agricultural practices in five decades. Biodivers. Conserv. 2018, 27, 3267-3286. [CrossRef]

4. Heap, I. The International Herbicide-Resistant Weed Database. Available online: www.weedscience.org (accessed on 30 July 2021 ).

5. Peterson, M.A.; Collavo, A.; Ovejero, R.; Shivraindand, V.; Walsh, M.J. The challenge of herbicide resistance around the world: A current summary. Pest Manag. Sci. 2018, 74, 2246-2259. [CrossRef]

6. Torra, J.; Rojano-Delgado, A.M.; Rey-Caballero, J.; Royo-Esnal, A.; Salas, M.L.; De Prado, R. Enhanced 2,4-D metabolism in two resistant Papaver rhoeas populations from Spain. Front. Plant Sci. 2017, 8, 1584. [CrossRef]

7. Stankiewicz-Kosyl, M.; Synowiec, A.; Haliniarz, M.; Wenda-Piesik, A.; Domaradzki, K.; Parylak, D.; Wrochna, M.; Pytlarz, E.; Gala-Czekaj, D.; Marczewska-Kolasa, K.; et al. Herbicide Resistance and Management Options of Papaver rhoeas L. and Centaurea cyanus L. in Europe: A Review. Agronomy 2020, 10, 874. [CrossRef]

8. Adamczewski, K.; Kierzek, R. Weeds resistance problem in Poland. Prog. Plant Prot./Post. Ochr. Roślin 2011, 51, 1665-1674. (In Polish)

9. Rola, H.; Rola, J. Amaranthus retroflexus, Chenopodium album, Echinochloa crus-galli-Biotypes resistant to triazine herbicides in corn in south-western Poland. Pam. Put. 2002, 129, 11-24. (In Polish)

10. Ciarka, D.; Gawroński, S.W. Wierzbownica gruczołowata-pierwszy w Polsce chwast wieloletni odporny na herbicydy triazynowe. Ochr. Rośl. 1997, 41, 2. (In Polish)

11. Jursik, M.; Holec, J.; Andr, J. Biology and control of another important weeds of the Czech Republic: Cornflower (Centaurea cyanus L.). Listy Cukrov. Reparske 2009, 125, 90-93.

12. Petit, C.; Arnal, H.; Darmency, H. Effect of fragmentation and population size on the genetic diversity of Centaurea cyanus L. (Asteraceae) population. Plant. Ecol. Evolut. 2015, 148, 191-198. [CrossRef]

13. Sutcliffe, O.L.; Kay, Q.O.N. Changes in the arable flora of central southern England since the 1960s. Biol. Conserv. 2000, 93, 1-8. [CrossRef]

14. Baessler, C.; Klotz, S. Effects of changes in agricultural land-use on landscape structure and arable weed vegetation over the last 50 years. Agric. Ecosyst. Environ. 2006, 115, 43-50. [CrossRef]

15. Kolárová, M.; Tyšer, L.; Soukup, J. Impact of site conditions and farming practices on the occurrence of rare and endangered weeds on arable land in the Czech Republic. Weed Res. 2013, 53, 489-498. [CrossRef]

16. Dabkowska, T.; Grabowska-Orzadała, M.; Łabza, T. The study of the transformation of segetal flora richness and diversity in selected habitats of southern Poland over a 20-year interval. Acta Agrobot. 2017, 70, 1712. [CrossRef]

17. Hofmeijer, M.A.; Gerowitt, B. The regional weed vegetation in organic spring-sown cereals is shaped by local management, crop diversity and site. Jul. Kühn Arch. 2018, 458, 288-294.

18. Staniak, M.; Haliniarz, M.; Kwiecińska-Poppe, E.; Harasim, E.; Wesołowski, M. Diversity of agrocoenoses in the Lublin region, Poland. Acta Agrobot. 2017, 70, 1722. [CrossRef]

19. Randall, J.M.; Marinelli, J. Invasive Plants: Weeds of the Global Garden; Science Press: New York, NY, USA, 1996 ; p. 112.

20. Marczewska, K.; Rola, H. Identification of resistant to chlorsulfuron of Apera spica-venti and Centaurea cyanus biotypes and chemical methods their control in winter wheat. Prog. Plant Prot. 2006, 46, 215-222.

21. Adamczewski, K.; Kierzek, R. Cornflower (Centaurea cyanus L) cross resistance on ALS inhibitors. Prog. Plant Prot./Post. Ochr. Roślin 2010, 50, 287-290. (In Polish)

22. Fuerst, E.P.; Sterling, T.M.; Norman, M.A.; Prather, T.S.; Irzyk, G.P.; Wu, Y.; Lownds, N.K.; Callihan, R.H. Physiological characterization of picloram resistance in yellow starthistle. Pestic. Biochem. Physiol. 1996, 56, 149-161. [CrossRef]

23. Miller, T.W.; Shinn, S.L.; Thill, D.C. Cross-Resistance in and Chemical Control of Auxinic Herbicide-Resistant Yellow Starthistle (Centaurea solstitialis). Weed Technol. 2001, 15, 293-299. [CrossRef]

24. Mangin, A.R.; Hall, L.M. First report: Spotted knapweed (Centaurea stoebe) resistance to auxinic herbicides. Can. J. Plant Sci. 2016, 96, 928-931. [CrossRef]

25. Adamczewski, K.; Matysiak, K.; Kierzek, R.; Kaczmarek, S. Significant increase of weed resistance to herbicides in Poland. J. Plant. Prot. Res. 2019, 59, 139-150.

26. Madej, A. Processes of concentration in cereal production in Poland. Pol. J. Agron. 2018, 35, 23-31. (In Polish) 
27. Sokólski, M.; Jankowski, K.J.; Załuski, D.; Szatkowski, A. Productivity, Energy and Economic Balance in the Production of Different Cultivars of Winter Oilseed Rape. A Case Study in North-Eastern Poland. Agronomy 2020, 10, 508. [CrossRef]

28. Burgos, N.L.; Tranel, P.J.; Streibig, J.C.; Davis, V.M.; Shanes, D.; Norsworthy, J.K.; Ritz, C. Review: Confirmation of Resistance to Herbicides and Evaluation of Resistance Levels. Weed Sci. 2013, 61, 4-20. [CrossRef]

29. Panozzo, S.; Scarabel, L.; Collavo, A.; Sattin, M. Protocols for Robust Herbicide Resistance Testing in Different Weed Species. J. Vis. Exp. 2015, 101, 1-10. [CrossRef]

30. Burgos, N.L. Whole-Plant and Seed Bioassays for Resistance Confirmation. Weed Sci. 2015, 152-165. [CrossRef]

31. Knezevic, S.Z.; Streibig, J.C.; Ritz, C. Utilizing R software package for dose-response studies: The concept and data analysis. Weed Technol. 2007, 21, 840-848. [CrossRef]

32. R Core Team, R. A Language and Environment for Statistical Computing; R Foundation for Statistical Computing: Vienna, Austria, 2020; Available online: https: / www.R-project.org/ (accessed on 8 June 2021).

33. Beckie, H.J.; Tardif, F.J. Herbicide cross resistance in weeds. Crop Prot. 2012, 35, 15-28. [CrossRef]

34. Rola, H.; Marczewska, K. Sulfonylurea herbicide resistant biotype of weeds in Wroclaw Region. Prog. Plant Protect. 2002, $42,575-577$.

35. Adamczewski, K.; Kierzek, R. Występowanie biotypów miotły zbożowej (Apera spica-venti L.) odpornej na herbicydy sulfonylomocznikowe. Prog. Plant Prot. 2007, 47, 333-340.

36. Stankiewicz-Kosyl, M.; Wrochna, M.; Salas, M.; Gawroński, S.W. A strategy of chemical control of Apera spica-venti L. resistant to sulfonylureas traced on the molecular level. J. Plant Prot. Res. 2017, 57, 113-119. [CrossRef]

37. Adamczewski, K.; Kierzek, R.; Matysiak, K. Multiple resistance to acetolactate synthase (ALS)- and acetyl-coenzyme A carboxylase (ACCase)-inhibiting herbicides in blackgrass (Alopecurus myosuroides Huds.) populations from Poland. J. Plant. Prot. Res. 2016, 56, 402-410. [CrossRef]

38. Varah, A.; Ahodo, K.; Coutts, S.R.; Hicks, H.L.; Comont, D.; Crook, L.; Hull, R.; Neve, P.; Childs, D.Z.; Freckleton, R.P.; et al. The costs of human-induced evolution in an agricultural system. Nat. Sustain. 2020, 3, 63-71. [CrossRef]

39. Comont, D.; Hicks, H.; Crook, L.; Hull, R.; Cocciantelli, E.; Hadfield, J.; Childs, D.; Freckleton, R.; Neve, P. Evolutionary epidemiology predicts the emergence of glyphosate resistance in a major agricultural weed. New Phytol. 2019, 223, 1584-1594. [CrossRef]

40. Rozkrut, D. (Ed.) Statistical Yearbook of Agriculture; Statistics Poland: Warsaw, Poland, 2020.

41. Moss, S.; Ulber, L.; Hoed, I. A herbicide resistance risk matrix. Crop Prot. 2019, 115, 13-19. [CrossRef]

42. Moss, S.R.; Perryman, S.A.M.; Tatnell, L.V. Managing Herbicide-Resistant Blackgrass (Alopecurus myosuroides): Theory and Practice. Weed Technol. 2007, 21, 300-309. [CrossRef]

43. Torra, J.; Royo-Esnal, A.; Rey-Caballero, J.; Recasens, J. Management of Herbicide-Resistant Corn Poppy (Papaver rhoeas) under Different Tillage Systems Does Not Change the Frequency of Resistant Plants. Weed Sci. 2018, 66, 764-772. [CrossRef]

44. Vijayarajan, V.B.A.; Forristal, P.D.; Cook, S.K.; Staples, J.; Schilder, D.; Hennessy, M.; Barth, S. First Report on Assessing the Severity of Herbicide Resistance to ACCase Inhibitors Pinoxaden, Propaquizafop and Cycloxydim in Six Avena fatua Populations in Ireland. Agronomy 2020, 10, 1362. [CrossRef]

45. Travlos, I.; Prado, R.; Chachalis, D.; Bilalis, D.J. Editorial: Herbicide Resistance in Weeds: Early Detection, Mechanisms, Dispersal, New Insights and Management Issues. Front. Ecol. Evol. 2020, 8, 213. [CrossRef]

46. Weisberger, D.; Nichols, V.; Liebman, M. Does diversifying crop rotations suppress weeds? A meta-analysis. PLoS ONE 2019, 14, e0219847. [CrossRef]

47. Massa, D.; Kaiser, Y.I.; Andújar-Sánchez, D.; Carmona-Alférez, R.; Mehrtens, J.; Gerhards, R. Development of a Geo-Referenced Database for Weed Mapping and Analysis of Agronomic Factors Affecting Herbicide Resistance in Apera spica-venti L. Beauv. (Silky Windgrass). Agronomy 2013, 3, 13-27. [CrossRef]

48. Beckie, H.J.; Harker, K.N. Our top 10 herbicide-resistant weed management practices. Pest Manag. Sci. 2017, 73, 1045-1052. [CrossRef] [PubMed]

49. Ngow, Z.; Chynoweth, R.J.; Gunnarsson, M.; Rolston, P.; Buddenhagen, C.E. A herbicide resistance risk assessment for weeds in wheat and barley crops in New Zealand. PLoS ONE 2020, 5, e0234771. [CrossRef] [PubMed]

50. Thornby, D.; Werth, J.; Hereward, J.; Keenan, M.; Chauhan, B. Herbicide resistance evolution can be tamed by diversity in irrigated Australian cotton: A multi-species, multi-herbicide modelling approach. Pest Manag. Sci. 2018, 74, 2363-2375. [CrossRef] [PubMed]

51. Adamczewski, K.; Kierzek, R. Mechanism of resistance on acetylolactate synthase (ALS) of Centaurea cyanus L. biotypes crossresistant. Prog. Plant Prot./Post. Ochr. Roślin 2011, 51, 317-324. (In Polish)

52. Gaines, T.; Duke, S.O.; Morran, S.; Rigon, C.A.G.; Tranel, P.; Kupper, A.; Dayan, F. Mechanisms of evolved herbicide resistance. J. Biol. Chem. 2020, 24, 10307-10330. [CrossRef] [PubMed]

53. Hada, Z.; Menchari, Y.; Rojano-Delgado, A.M.; Torra, J.; Menéndez, J.; Palma-Bautista, C.; de Prado, R.; Souissi, T. Point Mutations as Main Resistance Mechanism Together with P450-Based Metabolism Confer Broad Resistance to Different ALS-Inhibiting Herbicides in Glebionis coronaria From Tunisia. Front. Plant Sci. 2021, 12, 626-702. [CrossRef] [PubMed]

54. Kaloumenos, N.S.; Adamouli, V.N.; Christos, A.; Dordas, C.A.; Eleftherohorinos, I.G. Corn poppy (Papaver rhoeas) crossresistanceto ALS-inhibiting herbicides. Pest. Manag. Sci. 2011, 67, 574-585. [CrossRef] 
55. Kati, V.; Scarabel, L.; Thiery-Lanfranchi, D.; Kioleoglou, V.; Liberopoulou, S.; Délye, C. Multiple resistance of Papaver rhoeas L. to 2,4-D and acetolactate synthase inhibitors in four European countries. Weed Res. 2019, 59, 367-376. [CrossRef]

56. Walsh, M.J.; Owen, M.J.; Powles, S.B. Frequency and distribution of herbicide resistance in Raphanus raphanistrum populations randomly collected across the Western Australian wheatbelt. Weed Res. 2007, 47, 542-550. [CrossRef] 